\title{
CLASS ENGAGEMENT USING SOCIAL MEDIA
}

\author{
Mendez EA* and Lopez M \\ Escuela de Medicina y Ciencias de la Salud, Tecnologico de Monterrey, Mexico
}

\begin{abstract}
Many adaptations had to be made to classes worldwide amid the COVID-19 pandemic and keeping students engaged and interested in class became a priority for educators. This pandemic has posed a challenge since it forced schools to rapidly migrate the teaching-learning process to an online platform. Particularly, Gen-Z class engagement has been an issue for most teachers, because students tend to rapidly drift away from class; this, alongside the anxiety and stress over the future and the health of their loved ones, has made class engagement an even greater challenge. Using social media as a tool in class may seem unorthodox but given the main features that distinguish Gen-Z, it can be a useful tool to approach and engage them. In order to do so, three different phases of educational innovations were implemented, coronabunker, teaching with memes, and open thread. Each implementation built on the learnings from the previous one, to develop strategies targeted for the participants. The results indicated that students perceive these implementations as fun, when developing the posts from the thread activity, students stated that it also allowed them to integrate curricular content. This generation shares unique language and cultural references that may provide educators a rare glimpse to approach and start to build a bridge that would eventually diminish the gap between generations.
\end{abstract}

Keywords: medical education, digital education, distance learning, educational innovation, student engagement

\section{Background of the subject}

Characteristics between generations in the classroom deeply influence their interests and motivations, which they share in a rapidly changing world. In an educational community, currently, four distinct generations coexist, and each generation brings a unique set of core values and characteristics to an organization (Clark, 2017). The older generation is the baby boomers, born between 1944 and 1964; then, Gen X, born between 1965 and 1979; the Millennial generation describes individuals born between 1980 and 1994, and the youngest generation is the Gen Z, born between 1995 and 2015 (Francis \& Hoefel, 2018).

The students that are admitted and currently studying an undergraduate program are mainly Gen Z and take for granted the access to resources that complement the classroom experience. Educators are mainly Millennials and Baby boomers that have been educated in environments where face-to-face interaction was the norm to find books and multimedia resources. This generational gap between teachers and students has always been present in a classroom and this could easily interfere with a class dynamic, but also creates possibilities to enrich the educational community.

The rapid adoption of technology, such as wireless internet and mobile devices has changed the way in which the members of a community interact (Moore, Jones \& Frazier, 2017). Gen Z, the true digital natives have been exposed to the internet and social media throughout their entire lives and it has become an important part of their daily life. They spend several hours a day interacting with people 
from different places of the world, using these platforms. Social media usage has shaped the way they express ideas and the way they interact with one another (Hampton \& Keys, 2016). Networks such as Facebook, Twitter, and Instagram have had a deep impact on their daily lives and have become valuable communication tools.

Schwieger and Ladwig (2018) argue that Gen Zers crave personalized micro-experiences that are tailored to their needs, context, and convenience. These are elements part of the interconnectivity they have through their online windows to the world. By following friends, influencers, Instagrammers, and their idols, they interact with different traditions, cultures, and ideas. For Moore, Jones \& Frazier (2017) it translates to a crucial need in Gen $\mathrm{Z}$ education, to leverage all these unique cultural mixtures in an entrepreneurial streak to express their creativity and help them make meaningful connections of their knowledge.

Every generation has its own defining characteristics. GenZ lives in a world of continuous updates that translates to shorter attention spans (Schwieger \& Ladwig, 2018). The engagement of this generation often poses a challenge for teachers in face-to-face formats, and to do so in a virtual environment is an even greater challenge. Many works have highlighted the importance of keeping students engaged during class in order to promote environments that conduct thinking and creating, through new designs for classroom layouts, desks facing each other to enhance interaction, the inclusion of interactive technologies, and taking students outside the university walls (Cilliers, 2017).

The new generation of students are attracted to organizations that promote healthy practices and community building, organizations that care for them as a person; therefore, approaches like these must become the new norm for higher education environments (Eckleberry-Hunt, Lick \& Hunt, 2018). The application of strategies that promote community and connection between students and teachers must be systematic, to truly favor student empowerment. This can reduce the generational gap and later help the learning process making it a more enjoyable experience.

Rapid adaptations were made in the educational setting amid the COVID-19 pandemic. Migration into an online setting came with great challenge, not only for curricular delivery but also for interaction between teachers and students (Valdez-García et al., 2020). The virus transformed how we see and approach education and students, and it gave an insight into how education should evolve and find new ways of interaction between teacher and student (Habibi et al., 2018; Peña-Martínez \& Lopez, 2021). On the verge of this pandemic, students often faced uncertainty and isolation. Some of them may also have the perception that adaptation of the learning environment that the universities provided, should also include the community environment and social dynamics (Nieto \& Lopez, 2020). The integration of the whole university experience should include the academic continuity but also the community building dynamics among teachers and students in an online setting (Gilbert, 2018). Strategies that might be deemed as unorthodox could be the spark to engage students, but are yet to be explored (Berry, 2019).

\section{What was tried?}

Leveraging the use of social media as a tool in class may seem unorthodox but given the main features that distinguish Gen-Z, it may become useful to approach and engage them. In order to do so, three different educational innovations were implemented, Coronabunker (Mendez \& Lopez, 2020), 
teaching with memes (Mendez \& Lopez, 2020b), and Open thread. These approaches were applied sequentially, and the different stages represent learning that constructs the maturity of educators.

\begin{tabular}{|c|c|c|}
\hline $\begin{array}{l}\text { Coronabunker } \\
\text { - } 1 \text { month } \\
\text { - } 60 \text { students } \\
\text { - } 214 \text { posts }\end{array}$ & $\begin{array}{l}\text { Teaching } \\
\text { with } \\
\text { memes } \\
\text { - } 1 \text { month } \\
\text { - } 45 \text { students } \\
\text { - } 65 \text { posts }\end{array}$ & $\begin{array}{l}\text { Open } \\
\text { thread } \\
\text { - } 3 \text { weeks } \\
\text { - } 60 \text { students } \\
\text { - } 15 \text { threads }\end{array}$ \\
\hline
\end{tabular}

Figure 1: Process of implementation of educational strategies to foster class engagement

The participants were students from an undergraduate course of hematology and immunology at a private university in Latin America. The implementation ran during the first semester of 2020 where presence-based interaction shifted to a remote educational model.

\section{Coronabunker}

This educational innovation consisted of weekly optional activities for students to take part in as a means to promote relaxation amid pandemic and social distancing. Some of the activities included sharing a fun fact about animals, uploading an image of their pets studying with them, finding a joke or a meme. Activities were open during the weekend, reviewed at the end of the class and students could vote on their favorite post. Since this last activity was widely accepted by the class a second implementation was done. This activity was deemed optional and was not part of the grade.

\section{Teaching with memes}

This educational innovation consisted of students developing a meme related to the topics that were being discussed and reviewed in class. During the session, the memes were shared and they had to vote on their favorite by liking their fellow classmate's post, the winner would be acknowledged by everyone during class and given a round of virtual applause. This activity was deemed optional and was not part of the grade.

\section{Open thread}

The third approach, based on the good response the previous implementations had, another activity was designed. This consisted of developing a series of posts resembling 'tweets' and 'threads' present on social media like Twitter or Facebook but related to the course's topics. Students had the liberty to choose between all the syllabus for their favorite one. An oral explanation was given to the students during class about the requisite and the rubric for assessment was explained.

Students had 3 weeks to work on teams of five and develop between 10-15 tweets accompanied by an image. The final result was reviewed in front of the class in a synchronous session. To further assess students' perception of this particular activity, an online anonymous survey was conducted. It was 
clarified that their answers would not have an impact on their grades and to assure that the survey was sent once the final exposition was graded. This particular implementation was obligatory and the result would be part of their final grade for the third term of the semester.

\section{Lessons learned}

Each implementation built on the learnings from the previous one, to develop strategies targeted for the participants. The results indicated that students perceive these implementations as fun, when developing the posts from the thread activity, students stated that it also allowed them to integrate curricular content. As shown in table 1, class engagement could be monitored through the number of posts that the students developed, the students' perceived contribution of the activity, and the results of the survey at the end of the course.

Table 1: Key features of the experiences

\begin{tabular}{|c|c|c|c|}
\hline $\begin{array}{l}\text { Educational } \\
\text { innovation }\end{array}$ & $\begin{array}{l}\text { Number of } \\
\text { posts }\end{array}$ & $\begin{array}{l}\text { Key features of the } \\
\text { implementation }\end{array}$ & Students' perceived contribution \\
\hline Coronabunker & $214(n=60)$ & $\begin{array}{l}\text { Optional } \\
\text { Length: } \\
1 \text { month }\end{array}$ & $\begin{array}{l}\text { What worked: } \\
\text { Relaxed environment for self-care. } \\
\text { Community building focus. } \\
\text { Not part of the assessment. } \\
\text { What didn't work: } \\
\text { Some topics were not interesting for } \\
\text { students. }\end{array}$ \\
\hline $\begin{array}{l}\text { Teaching with } \\
\text { memes }\end{array}$ & $64(n=45)$ & $\begin{array}{l}\text { Optional } \\
\text { Length: } \\
1 \text { month }\end{array}$ & $\begin{array}{l}\text { What worked: } \\
\text { Funny and clever ideas to represent } \\
\text { complex topics. } \\
\text { Students competed with each other to } \\
\text { have a clever approach. } \\
\text { What didn't work: } \\
\text { The authors had no downside on this } \\
\text { implementation }\end{array}$ \\
\hline Open thread & $12(\mathrm{n}=60)$ & $\begin{array}{l}\text { Mandatory } \\
\text { Length: } \\
3 \text { weeks }\end{array}$ & $\begin{array}{l}\text { What worked: } \\
\text { Fun as it included jokes and cultural } \\
\text { references. } \\
\text { Integrative experience. } \\
\text { Build-in social media. } \\
\text { What didn't work: } \\
\text { Some students felt the time invested in } \\
\text { designing the thread could be invested in } \\
\text { studying. } \\
\text { Some students felt the grading rubric } \\
\text { hampered creativity. }\end{array}$ \\
\hline
\end{tabular}

In the Coronabunker experience, students showed interest in this first dynamic. Even though they participated in these activities, the one that attracted them the most and had an enormous response was the one where they had to upload a funny meme that made them laugh. Some students posted more 
than once and when the session started they specifically asked for time to see everyone's images. This gave way to the next implementation.

In the Teaching with memes, experience 64 memes were designed by a total of 45 students. Memes were shared during the synchronous sessions, students themselves asked for time to review the images they submitted. Most images were focused on the learning and described. Overall, the acceptance of this activity was far more than expected.

In the \#OpenThread experience a total of 12 threads were developed by 60 students. Surprisingly, some teams made a real Twitter account specifically for this assignment, some others designed their own memes or gifs to further express what they wanted to communicate on the 'posts', even though it was not part of the evaluation criteria on the rubric they were given. This showed the commitment and engagement this implementation had on students.

One example of the threads narrates in detail all the phases of the T-cell development in the thymus and how it forms its specific receptor but using only images from the movie Mean Girls. It compares an immature cell arriving at the thymus (generator organ) with the protagonist arriving on the first day of school. Another 'tweet' depicts the main character interacting closely with the boy she likes, comparing this with the interaction of an immature cell with the stromal cells that help them to develop. Another showed her kissing the boy, this, resembling how the final stimulus for the maturation is given to the T-cell. After the last phase was implemented, an anonymous online survey with a five-point Likert scale was sent to the students once the activity was completed and graded. The aim of this was to assess their satisfaction with the Thread activity.

The questionnaire also included an open-ended question asking for feedback on the activity. Some of the comments that gave insight on opportunity areas were that students perceived that since the activity was obligatory and the rubric was too strict their creativity could be hampered and the activity less enjoyable, nevertheless, the majority of them perceived the activity as fun.

\section{Conclusion}

The ideas experienced an evolution through the course of the semester, each implementation gained insight on what worked with the students, a key factor was listening to them and observing their response to the activities to further construct or re-think the next one. Another interesting process was the maturation process of the educator, as the development of the project was engaging it was also a strenuous process of planning and adaptation. But the iteration on the implementation impacts the definition of the effectiveness of the class.

Class engagement can become an issue for teachers, especially when a big generational gap exists between them and their students, social media presents a great opportunity to approach and communicate with them, providing also the means to spark their engagement in class (even in a distance learning environment). This can set the tone for exploring different activities and using unorthodox media to promote class engagement. For example, educators can follow trends in social media to understand what students are using to communicate and being part of a community. By doing so, educators can adapt these to the class environment and analyze its effects. Although building on previous lessons constitutes a keystone, it is important to change the mindset to a continuous improvement for educational innovations that engage students. 


\section{Acknowledgments}

The authors would like to acknowledge the financial support of Writing Lab, TecLabs, Tecnologico de Monterrey, Mexico, in the production of this work.

The authors would like to dedicate this work entirely to the students that collaborated, showed interest and commitment in the activities. Despite the pandemic being difficult for everyone, they were present and open to try new things. The successful delivery could not have happened without them.

\section{References}

Berry, S. (2019). Teaching to Connect: Community-Building Strategies for the Virtual Classroom. Online Learning, 23(1), 164-183.

Cilliers, E.J. (2017). The Challenge of teaching generation Z. PEOPLE: International Journal of Social Sciences, 3(1), 188-198.

Clark, K. R. (2017). Managing multiple generations in the workplace. Radiologic technology, 88(4), 379-396.

Eckleberry-Hunt, J., Lick, D., Hunt, R. (2018). Is Medical Education Ready for Generation Z? J Grad Med Educ, 10(4), 378-381.

Francis, T., \& Hoefel, F. (2018). True Gen': Generation Z and its implications for companies. McKinsey \& Company, 12.

Gilbert, L. (2018). "Not just bow and string and notes": Directors' perspectives on community building as pedagogy in Celtic traditional music education organizations. International Journal of Music Education, 36(4), 588-600. https://doi.org/10.1177/0255761418774938

Hampton, D.C., Keys, Y. (2016). Generation Z students: Will they change our nursing classrooms? Journal of Nursing Education and Practice, 7(4), 111-115.

Habibi, A., Mukminin, A., Riyanto, Y., Prasojo, L. D., Sulistiyo, U., Sofwan, M., \& SAUDAGAR, F. (2018). Building an online community: Student teachers' perceptions on the advantages of using social networking services in a teacher education program. Turkish Online Journal of Distance Education, 19(1), 46-61.

Méndez Reguera, A., \& López Cabrera, M. V. (2020). Coronabunker: Let's just not talk about 'it'. Medical education, 54(11), 1053-1054. https://doi.org/10.1111/medu.14306

Mendez-Reguera, A., \& Lopez Cabrera, M. V. (2020). Engaging My Gen Z Class: Teaching with Memes. Medical science educator, 1-2. Advance online publication. https://doi.org/10.1007/s40670020-01078-w

Moore, K., Jones, C., Frazier, R.S. (2017). Engineering education for Generation Z. American Journal of Engineering Education, 8(2), 111-127.

Nieto, A., López, M. (2020). One giant leap for mankind: The experience of studying medicine through the pandemic. MedEdPublish, 9. https://doi.org/10.15694/mep.2020.000274.1

Peña-Martínez, H., López, M. (2021). The COVID-19 Pandemic: The 2020s Cataclysm for Traditional Medical Education [La pandemia de la COVID-19: el cataclismo del 2020 para la educación médica tradicional]. Educacion Medica. DOI: 10.1016/j.edumed.2020.11.006

Scwieger, D., Ladwig, C. (2018). Reaching and retaining the next generation: adapting to the expectations of Gen Z in the Classroom. Information Systems Education Journal, 16(3), 45-54.

Valdez-García, J.E., Lopez, M., Jiménez, M.A., Díaz Elizondo, J.A., Dávila Rivas, J.A., Olivares, S. (2020). Me preparo para ayudar: respuesta de escuelas de medicina y ciencias de la salud ante 
COVID-19. Investigación en educación médica, 9(35), 85-95. DOI: https://doi.org/10.22201/facmed.20075057e.2020.35.20230 